\title{
Strangers at home: The Textual Construction of the Sherley Brothers*
}

\author{
Jesús López-Peláez Casellas \\ Universidad de Jaén
}

\begin{abstract}
During the first half of the seventeenth century various written accounts of the adventures of the three Sherley brothers Thomas, Anthony and Robert - were published in England. These texts, in some cases written by the Sherleys themselves, often contributed to building an unproblematic and positive vision of the three brothers and their adventures in Persia, Turkey, and throughout Europe. However, an examination of the way in which all these texts (pamphlets, autobiographical writings, travel accounts, government documents, and private and official letters) interact with each other, together with the additional information provided by French and Spanish documents not accessible to an early modern audience in England, allows us to retrieve a Sherleyan narrative which, like the period in which it was produced, appears full of contradiction and new meanings.

KEYWORDS: Anthony Sherley, Robert Sherley, Thomas Sherley, seventeenth-century texts, Persia, Turkey, Spain, travel literature, pamphlet literature.
\end{abstract}

\footnotetext{
* The research conducted for this paper was financed by the Research Project "Musulmanes, españoles y judíos en los textos pre-modernos en lengua inglesa: La construccion del otro" (Proyecto I+D ref. FFI2009-13165). I am grateful to the Folger Shakespeare Library (Washington DC) and to the Biblioteca Nacional de España (Madrid) for permission to access their early modern collections. I also thank my friend and colleague Eroulla Demetriou for her valuable comments and careful revision of the original manuscript.
}

$$
\text { (E) ederi } 23 \text { (2013: 33-56) }
$$

https://doi.org/10.34136/sederi.2013.2 


\section{Introduction}

During the early seventeenth century, various written texts of diverse sorts dealing with the adventures and (mostly failed) political projects of the three Sherley brothers, Thomas, Anthony and Robert, were published in England, France and Spain, consequently making knowledge of their exploits widespread. ${ }^{1}$ Indeed, any discussion of the relations of England with Persia (and to a lesser extent with Turkey and Spain) in the early seventeenth century must necessarily consider the narratives of the three Sherley brothers' adventures. These texts, mostly written by participants in their exploits, fashion the Sherleys as typically Elizabethan adventurers endowed with a characteristic and fascinating combination of political ambivalence, boundless ambition, and opportunism. The texts also claim that the brothers' changing allegiances made them serve their Queen (and later their King) with courage until it was in their best interest to shift their allegiance to some other influential power (sometimes serving both English and foreign monarchs simultaneously).

Given their ambiguous relations with England, Protestantism and the Crown, in the eyes of Englishmen of the early seventeenth century they were controversial figures, more to be mistrusted than admired. $^{2}$ On the other hand, Anthony Nixon's well-known pamphlet of 1607, The Three English Brothers, calls them the "three heroes of our time," and complains that the three brothers, being respected figures abroad, were unfairly and cruelly ignored by their own countrymen: "they were unkindly used by us, to be made

\footnotetext{
${ }^{1}$ As we will see, the Sherley brothers became especially popular between 1607 (the date of publication of a first pamphlet and the play about them) and 1613 (when Sir Anthony's own account of his travels appeared in England). However, their popularity did not disappear after 1613: Samuel Purchas was still writing in praise of them in Purchas His Pilgrimes in 1625, and the last eye-witness account of the Sherleys' exploits was published, in French, as late as 1651.

${ }^{2}$ There is sufficient evidence to support this view: their image was so seriously damaged that the eldest brother, Thomas, in 1607 tried to improve it through a pamphlet and a play, both of which he appears to have commissioned (Andrea 2008:45; Masood 2011:168). Also, Anthony Parr has shown how as early as 1602 Thomas and Anthony's expeditions had attracted strong criticism, from among others the letter-writer John Chamberlain (Parr 1996:15). Besides, Anthony Nixon himself, as we will see below, complained about the "unkindness" of contemporary Englishmen towards the Sherleys in his 1607 pamphlet.
} 
strangers here at home" (B-B2). In fact, there is a wide variety of contemporary sources about the three brothers, and whereas some were easily accessible to the English reading public of the age, some others were unknown to most, both then and today. Among the former are a few pamphlets and first-hand accounts, Day, Wilkins and Rowley's 1607 play, ${ }^{3}$ and the Sherleys' autobiographical narratives of their adventures. As for those documents not known by their contemporaries, they include letters by the brothers that were intercepted by the government and filed among state papers, reports by agents working for the various monarchs they served, and narratives and reports by or about them in French and Spanish. This diversity of sources makes it more difficult to determine the Sherleys' real significance in the period and to explain the oblivion into which everything surrounding them fell by the late seventeenth century (Parr 1996:15), including their reputations as "rogue Englishmen:" truculent, ineffectual and disloyal individuals who were inevitably obscured by the "glory of greater men" (Chew 1937:338).

In this essay I will explore most substantially relevant documents by or about the Sherleys (that is, pamphlets, private letters, government reports, and the brothers' own accounts of their adventures), ${ }^{4}$ and I will argue that all these texts offer competing versions of their activities. More specifically, I will read them as instances of early modern discontinuity, ambiguity and paradox which make it impossible for us to retrieve a single and coherent Sherleyan narrative. I will suggest that the non-English versions of this narrative interfere with, and call into question, the propagandistic and apparently harmonic construction of the so called "Sherley myth" (Parr 1996:15). ${ }^{5}$

\footnotetext{
${ }^{3}$ The play is John Day, George Wilkins and William Rowley's, The Travels of the Three English Brothers (1607), which was commissioned by the Sherley family and was heavily indebted to Anthony Nixon's pamphlet of the same year.

${ }^{4}$ I will focus on most of the non-literary sources in English, French and Spanish, leaving aside Persian sources, excluding from my study the 1607 play by Day, Wilkins and Rowley.

${ }^{5}$ Among the non-English sources I will be paying special attention to texts by or about the Sherleys in Spanish. These, apart from constituting interesting material that may contribute, substantially, to our understanding of the actual textual construction of the Sherleyan narrative, are significantly absent from most discussions of the three brothers and their exploits, since there are to date no English editions available.
} 
As Jonathan Burton has argued, in order to approach texts such as these without undervaluing all the non-English components, or reading history backwards, a "historiographical recentering" that problematizes the received histories of imperial continuity is required (2009:27-29). Through this, Burton means "to interrogate established narratives of continuity, or proto-modernization" that have permeated post-Saidian early modern studies on the so-called Muslim other (2009:28). Following Nabil Matar, whose approach emphasises Muslim agency and denies the existence of Orientalist (in the Saidian sense) practices in early modern texts (Matar 1998:120), Burton proposes to compare similar histories (or narratives) in more than one region, without privileging the Western (in our case English) discourse (2009:28). Similarly, I will argue that, if anything, the contradictions we find in the various accounts of the exploits of the Sherleys show how these cross-national discontinuities operate. Furthermore, I will highlight how all these sources, with their conflicting versions as well as complementary interpretations, not only illuminate the Sherleyan narrative as an instance of early modern intertextuality, a Genettian palimpsest (or the Lotmanian semiosphere, a space of semiosis - Lotman 2001:126-131), but also address the complexity of the notion of the global early modern ${ }^{6}$ that the Sherleys, more than most, exemplify.

\section{2. "Heroes of our Time"}

More than any other text (with the possible exception of Day, Wilkins and Rowley's play, which was closely based on it), Nixon's pamphlet The Three English Brothers (London, 1607), was designed to foster the Sherleys' reputation as:

worthy personages whose Noble spirits [...] have drawn other Nations into admiration of their valours and emulation of their

\footnotetext{
${ }^{6}$ I use this notion, which I borrow from Jonathan Burton, to refer to the so-called New World History's current emphasis on reexamining the discourse of Eurocentrism, interrogating "established narratives of continuity, or proto-modernization" (2009:28) and refusing to privilege European (the English sources of the Sherleyan exploits, in our case) categories. See for example the collection of essays recently edited by Jyotsna G. Singh, A Companion to the Global Renaissance: English Literature and Culture in the Era of Expansion, which explores how "English literature and culture of the period [...] are clearly imbricated within the larger imaginings of the 'worlds elsewhere,' which were brought home via a new cosmopolitanism" (6).
} 
virtues, [...] the Three Heroes of our Time; [...] Honour by them has added to her [i.e., England's] glory. (Nixon 1607:B-B2)

Anthony Parr convincingly argues (as Chew had already claimed) that Nixon's text was probably commissioned by Thomas Sherley (the eldest brother) in December 1606, soon after his return to England from his two-year imprisonment in Constantinople (Parr 1995:6; 1996:18; Chew 1937:287-288). Such a propagandistic text was apparently necessary because, during this period (late 1580s to 1607), the three brothers had been involved in dubious enterprises ${ }^{7}$ around the world (Parr 1996:15), calling into question the nature of their allegiances to various monarchs. Furthermore, the two youngest brothers - Anthony and Robert - had become Catholic from about 1598-1600 (Chew 1937:271), and Sir Thomas Sherley the elder had additional financial and legal troubles. Consequently, the family's name was far from untarnished (Schleck 2011:61-93).

From a more political perspective, Nixon's pamphlet was also devoted to promoting Anthony and Robert's attempt, after their arrival in Persia in December 1598, to encourage a Christian-Persian alliance against the Ottomans. Hence the pamphlet could be defined as an "interventionist" text, that is, one that is intended to influence public opinion on a current issue. ${ }^{8}$ Consequently it focused on the so-called "Persian adventure" of Anthony and Robert between 1599 and 1601 (the embassy that took Sir Anthony and an Anglo-Persian contingent to various European courts on a diplomatic mission) together with Thomas's Mediterranean campaign and subsequent imprisonments in Negroponte and Constantinople.

\footnotetext{
7 Sir Anthony narrates many of his (eventually unsuccessful) plans for a Spanish readership in Pesso politico de todo el mundo (Madrid, 1622), which recounts his fruitless embassy in Barbary on behalf of Emperor Rudolf, his participation in a failed AngloMoroccan plan to attack Spain, his role in promoting the marriage between Mary Stuart and the Duke of Parma in the late 1580 s, and his self-proclaimed active proSpanish role in the attempted Armada invasion (163-169v). Thomas's infamous Mediterranean raids on peaceful villages (1598-1602), and Robert's Persian marriage and eventual employment as the Sophy's ambassador (from 1599) also added to a generalized skepticism about the three brothers' merits and allegiances (T. Sherley 1936:iii-xii; Shand 1983:257-258).

${ }^{8}$ I borrow the term from Laurence Publicover, although he specifically applies it to Day, Wilkins and Rowley's play (Publicover 2010:695). Publicover holds that the play is part of a "public relations campaign" defending a "controversial political programme" (2010:695).
} 
Nixon's pamphlet was not original either: it was based on information provided by the eldest brother, Thomas Sherley (from his diary, preserved at Lambeth Palace), and especially on eyewitness accounts of various episodes of the Persian expedition, written by actual participants who, being in the service of Anthony and Robert, mostly praise them as exemplars of English virtue, courage and wit. These texts are the anonymous A True Report of Sir Anthony Sherley's Journey (160o); William Parry's A New and Large Discourse of the Travels of Sir Anthony Sherley, Knight (1601); and George Manwaring's A True Discourse of Sir Anthony Sherley's Travel into Persia (1601). From these direct sources Nixon literally lifted whole passages. ${ }^{9}$ Other documents about the Sherleys dealt with the Persian adventure, though they were not in English, or contemporary to the events described, or both. Consequently, while they also contributed substantially to the construction of the Sherleyan narrative, these other documents neither had a direct influence on Nixon or the play, nor became as popular as either. These documents are the autobiographical Sir Anthony Sherley. His Relations of his Travels into Persia (1613); John Cartwright's The Preacher's Travels (1611); Abel Pinçon's Relation d'un voyage de Perse (composed in 1605, though not published in Paris until 1651); and the illuminating Relaçiones de Don Juan de Persia (Madrid, 1604), by a certain Uruch Beg, who, after converting to Catholicism in Spain, became Don Juan de Persia. As we will see, both Pinçon's and Don Juan's narratives (especially the latter), unknown in England during at least the first half of the seventeenth century, interrogate the positive picture of the Sherleys, especially that of Sir Anthony, provided by English sources.

Of all these documents, Relaçiones is clearly the most interesting. Written by one of the Persian secretaries of Huseyn Ali Beg, the ambassador of the expedition, it was originally published for a Spanish Catholic readership and was completely unknown in early modern England, a fact which explains its invisibility for Nixon, Parry, Manwaring, or the three playwrights. Sir Anthony was lucky this was so, since in his account of the failed embassy of 1599-1601 Don Juan/Uruch Beg portrays Sir Anthony as a charlatan, liar, and murderer. Furthermore, he reduces Anthony's participation to a very

${ }_{9}^{9}$ Compare, for example, Nixon ( $\mathrm{H}_{4}-\mathrm{I} 1$ ) and Thomas Sherley's Discourse (1-2), with literally identical phrasing describing the Turks. 
marginal role, in marked contrast to the English texts. Indeed, Nixon's laudatory pamphlet was simply following similar (earlier) narratives. Thus, the anonymous True Report praises Sir Anthony for the "Free privileges obtained by Sir Anthony Sherley of the Great Sophy for all Christians to trade and traffic into Persia" (Ross 1933:96); Parry describes at length the Shah's admiration, bordering on infatuation, for Sir Anthony (Ross 1933:116-120); and Manwaring presents him as a leader who, while travelling through Persia, "desired to endure any torments himself, so that his company might pass quietly without hurt" (Ross 1933:193). It is against this consensus on the heroic stature of Anthony Sherley that we may read Don Juan of Persia's Spanish narrative.

Don Juan, who is not especially interested in the figure of Anthony Sherley (evidently his text has a different goal), unambiguously claims that he "had always had a mind to get the better of us" (Persia 1926:261), and provides some descriptions of Sir Anthony Sherley which interrogate the standard narrative of a heroic and honourable English hero. The episode concerning the disappearance of a friar provides a good example of this conflicting discursive production of Sir Anthony:

It was our suspicion that Sir Anthony Sherley had made away with him, for at the time when we were voyaging up the river Eder in the galleys, he had often threatened to kill the Friar, and for a time had kept him prisoner down below decks in a cabin of the galley. [...] For the Friar had explained to us that he had lent Sir Anthony a thousand crowns, and further entrusted him with ninety small diamonds to keep safe for him, and that it was because he had wanted these and the money back from Sir Anthony that he was so treating him to compass his destruction. (Persia 1926:258)

Comparing the English propagandistic texts with Don Juan's (proSpanish) unsympathetic description of Sir Anthony's wretchedness and petty machinations during the embassy (which ranged from grossly stealing the Shah's gifts to the Pope, to probably killing the friar, to whom he apparently owed some money) complements our understanding of the transnational Sherleyan narrative by providing us with a complex and unexpectedly rich mosaic of the multiple identities of Anthony Sherley which his English contemporaries lacked. 


\section{The Persian adventure}

Don Juan's narrative, as has been stated above, basically dealt with the so-called European (or Persian) embassy, the adventure for which the Sherley brothers were mostly admired in the early seventeenth century, and remembered for decades after. This embassy $^{10}$ apparently had the intention of, firstly, promoting commercial relations with Persia and, secondly, persuading Shah Abbas (who was known in early modern England as the Great Sophy) to join Christendom in a military league against the Turks. This league, Sir Anthony apparently suggested, should combine the forces of the Habsburg monarchs, Venice, and the Pope (Chew 1937:250; Burton 2009:23-24; Publicover 2010:699-700). Neither of the two goals was successfully accomplished or pioneering (Chew 1937:225-237,266-269); as a matter of fact, Elizabeth had officially decided to begin commercial relations with Persia as early as 1561, having sent a number of letters to the Shah to that effect (Hakluyt 1903:III, 7-8). However, from the 1580 os England had embarked on a policy of friendship with the Ottomans by means of the Levant Company, and consequently trade agreements or military alliances with the Sophy were now subordinated to the changing interests of Elizabethan England's politics (i.e., a strategic approach to Turkey, Spain's major enemy) (Chew 1937:250). With the accession of James I to the throne, the overtly friendly attitude towards the Porte was utterly rejected to the extent that even to communicate with the Turks on matters of commerce was forbidden. Additionally, as early as 1601, even before he had succeeded to the English throne, James was already trying to side with the Persians in their intermittent military conflicts with the Ottomans; this, however, had little impact on the Persian adventure since by late 1602 what remained of the embassy was already back in Persia (Jones 1978:163-168; Dimmock 2005:3-4,141; McJannet 2009:147-155; Chew 1937:277-278). The second goal that the Sherleys pursued, namely the creation of a combined Christian-Persian military front against the Turks, was grounded on the religious enmity existing between the Persians,

\footnotetext{
${ }^{10}$ The embassy included, apart from Sir Anthony (Robert Sherley stayed in Persia with the Sophy as a hostage): William Parry, George Manwaring, and Abel Pinçon plus four other Englishmen, the Persian ambassador Husayn 'Ali Beg, his four secretaries (one of whom was Uruch Beg, later Don Juan of Persia), and two Portuguese friars: the Franciscan Alfonso Cordero, and the Augustinian Francisco de Melo (Ross 1933:22; Chew 1937:261-264).
} 
who were Shi'ites, and the Turks, who were orthodox Sunnis, as we will see.

According to his autobiographical account, Sir Anthony's plan, unaware of (and almost uninterested in) late Elizabethan foreign policy, consisted of uniting all Christian princes and joining them to the Persian Sophy in order to confront the Turks (A. Sherley 1613:8083). Significantly, all English sources agree in describing this project as entirely engendered by Sir Anthony. According to Parry, "Sir Anthony ceased not to animate him [the Sophy]" and "possessed the King with [...] a burning desire to invade the Turk's dominions" (Ross 1933:118). Manwaring gives a similar, if only slightly more detailed, account:

Sir Anthony altered the King's mind, persuading him to send to all the princes in Christendom, which he was assured the Queen would like well of and to be in league with them all, and he would undertake to accomplish the embassage; and, moreover that he would maintain wars against the Turk on that side of him, and he would work so with the Christian princes that they should maintain wars on the other side, and so by that means overthrow him. The which matter the King was exceeding glad of, giving Sir Anthony many thanks for his good invention. (Ross 1933:222-223)

Abel Pinçon also presents the Persian-Christian alliance as Sir Anthony's "good invention," for which the Sophy was "exceeding glad of" (Ross 1933:223). Nixon summarizes this project, which he also attributes to Anthony Sherley:
Sir Anthony ceased not, during the time he lay in the Cittie, by all importune meanes, and forcible reasons, to animate and incense the Persian: alleaging how easy a matter it were for him, by his meanes, being a Christian, to joyne many of the Christian princes, his borderers, in League and friendship with him, and draw them to the assistance of these wars, both his supply in his owne Countrey, and als with powerfull invasions in many other places of the Turkes dominions, farre remote. $\left(1607: \mathrm{H}_{3}\right)$

Don Juan of Persia, however, gives a significantly different version of this event: "to this end, namely, war with the Ottoman power, the timely arrival of certain Englishmen gave him [ie, the Sophy] much encouragement" (Persia 1925:227). The project, according to Don Juan, had already been conceived by the Sophy, and the English brothers simply "arrived in the very nick of time," for the Sophy was already "preparing to send an ambassador with many gifts to the 
king of Spain, by way of the Portuguese Indies" (Persia 1925:232). Don Juan's account, then, clearly disputes Sir Anthony's claim to having played a central role in this high political decision.

This project was not, in any case, supported or inspired by the English (Elizabethan) government, which - as we saw above - was at the time (1598) eagerly trying to negotiate with the Ottomans against their common enemy, Habsburg Spain, a diplomatic move that, as I explained, would soon change under the Stuart monarch (Bak 1996:212-216). There is some evidence of the discomfort with which England followed the Sherleys' projects in Turkey and Persia: we know that William Cecil instructed the English ambassador at the Great Porte, Henry Lello, to discredit Sir Anthony in October 1600 as a rebel who had been "reproved in England for his folly" (Chew 1937:267). Furthermore, Sir Anthony was closely watched as an "impudent and inconvenient adventurer who [...] [had] arrogated to himself the title of English envoy to Persia," as Chew explains (1937:266). Indeed, it seems that Sir Anthony had actually proceeded in such a way, although no English narrative on the Sherleys makes any reference to it. Importantly, it is again from Don Juan that we learn that

He [Sir Anthony] gave himself out as cousin of the Scottish king James, saying that all the kings of Christendom had recognized him as such, and had now empowered him as their ambassador to treat with the king of Persia, who should make a confederacy with them in order to wage war against the Turk, who was indeed the common enemy of all of them. (Persia 1926:232) ${ }^{11}$

But "English envoy to Persia" was not the only title that Sir Anthony gave himself, as it appears that his claim to be the Sophy's ambassador and leader of the European expedition were not true. According to the Calendar of State Papers. Colonial Series, "in 1599 Shah Abbas sent over by Sir Anthony Sherley a declaration of his desire to be at peace with the Christian Princes" (1964:263/103). Manwaring actually explains how, after the Sophy invited Sir Anthony to lead his embassy to Europe, it was Sherley who "request(ed) the King to send a Persian along with him" (Ross 1933:223), and Nixon makes clear that Sir Anthony was the

\footnotetext{
${ }^{11}$ Furthermore, according to E.P. Shirley, Henry Lello wrote to Cecil in August 1598 that Sir Anthony Sherley had requested from him a passport, falsely claiming to be on business for Queen Elizabeth (1848:17).
} 
ambassador (Nixon 1607:H3-H3v). However, some non-English accounts seem, again, to dispute this. Don Juan affirms that the Sophy gave orders "proposing that Sir Anthony should accompany his envoy the Persian ambassador" (233), and Pinçon, for his part, simply says that "the Sophi sent him [Anthony Sherley] back to Christendom with one of his nobles, bearing presents and letters" (Ross 1933:164). Although his precise role in that embassy is, to this day, unclear, it appears that the official ambassador was the Persian nobleman Hussein Ali Beg, and that Sir Anthony's role was intended to be subservient to his, if only because the Shah was an experienced ruler, Ali Beg a trustful courtier, and Sir Anthony a foreigner newly arrived in Persia (Burton 2009:32-37; Gil 1985:352,366-368). Yet English sources endeavoured to present Anthony (and to a lesser extent Robert) Sherley as both the instigator of this embassy and its leader.

Anthony Nixon's text also claims that the Sophy, who according to Nixon liked Sir Anthony's project and trusted him, resolved to commission Sir Anthony - essentially on account of his being a Christian - to go to Christian courts to propose this league (1607: $\mathrm{H}_{3}-$ $\mathrm{H}_{3 \mathrm{v}}$ ). Interestingly given the Sherleys' uncertain religious allegiances as Protestant and Catholic, it would seem that it was Sir Anthony's Christian identity that convinced the Sophy to make him an important member of the embassy. According to the writings of Alfonso Cordero, one of the two Portuguese friars also travelling with the embassy, neither Shah Abbas nor Ali Beg, the Persian ambassador, had a clear idea about which European courts to visit: as Cordero puts it, the Sophy did not know "qué sea Inglaterra, ni Flandes, ni tiene más noticia que los títulos" (qtd in Gil 1985:352). Consequently, he needed Sir Anthony on account of his alleged knowledge of European courts.

But if, for the English, the Persian adventure could be described as controversial because it involved an alliance with a non-Christian nation, the simultaneously ambiguous and popular nature of this exploit, that evidently captured the imagination of the Elizabethans, must have had much to do with Sir Anthony's disturbing connections with the Earl of Essex (Ross 1933:8-10). To this we must add some of Sir Anthony's crucial decisions, namely why he never returned to England from Venice to support Essex's ill-fated plot, and why he decided, instead, to proceed to Persia in 1598, in both 
cases apparently following direct orders by the Earl or led by obscure motives, (Ross 1933:12-13; Chew 1937:239-242). Indeed, Sir Anthony's autobiographical writing of 1613 contributes to this confusing and somewhat mysterious narrative about the reasons behind his voyage to Persia. While according to Parry and Manwaring (Ross 1933:176) the idea of going to Persia came after conversing in Venice with a Persian merchant and an Italian translator, Sir Anthony's own account gives very different reasons:

Hee [Essex] proposed unto me (after a small relation, which I made unto him from Venice) the voiage of Persia, grounding of it upon two points. First, the glory of God. Then, [...] by making a profitable experience of my seeing those Countries, limitting upon the King of Spaines small parts, and answering to her Majesties Merchants trades in Turky, and Muskovy. [...] Besides, some more private designes, which my fortune, being of the condition, which my persecutions have brought it into, counselleth mee not to speake of. (A. Sherley 1613:4-5)

To my knowledge, Sir Anthony does not explain anywhere what that "small relation" he sent to Essex was about, what the "private designes" that sent him to Persia were, or why his current situation "counselleth" him "not to speake of" them. What Anthony Sherley does argue is that his relationship with Essex had condemned him, and that, if he had followed the Earl, it was "constrained by extremest necessity," as he complains in a letter to Cecil that predates his 1613 narrative (Calendar of State Papers. Domestic 1601-03 1870:223). After recounting his many services to England, he claims:

but all has been lost with one man. I wish my actions to be considered apart from the Earl of Essex, and to be judged by their merit. I hear of no one whose affection to the Earl has proved so pernicious to himself as has mine, though furthest removed from him. (Calendar of State Papers. Domestic, 1601-03 1870:224)

In another intertextual twist, and obviously aware of the inevitable associations between the Sherleys and his one-time patron the Earl of Essex, Nixon (in his account of Sir Anthony's "adventures and voyage into Persia") introduces a useful and equally intriguing comparison between Anthony Sherley and that Elizabethan paradigm of treachery, Captain Thomas Stukeley. Stukeley had become for the early modern English mind the quintessential traitor, the antithesis of the sixteenth and seventeenth centuries' concern with honour and reputation. This sharp contrast immediately 
introduced an additional textual layer of significance in the Sherleyan narrative: whereas Anthony Sherley is defined by Nixon as having "principally before him the prospect of honour," Stukeley only has "his desire upon a luxurious and libidinous life;" and whereas the former has "inlarged" his fame by means of "his honourable plots and imployments, against the enemie of Christendome," the latter is characterized by "treacherous designes [...] on behalf of the Pope, against his countrie" (1607:G1v). This emphasis on Anthony's loyalty through his contrast with a notorious traitor such as Stukeley evidently responds to the author's need to address the controversial matter of both Anthony's and Robert's recent conversion to Catholicism, of which readers must have been aware, most especially in the context of the Sherleys' involvement with Essex. This paradoxical and somewhat confusing triangular relation between the figures of Essex (originally a man of repute, eventually a man condemned), Stukeley (evil through and through) and Sir Anthony (whose reputation was in the (un)making) can only be explained by reference to Elizabethan honour in its various forms: military, chivalric, public and private (James 1978:309-325). Essex through his eventual revolt - represented the decline of some Elizabethan symbols linked to honour, ${ }^{12}$ and thus Stukeley is introduced in order to clarify (by contrast) Anthony Sherley's position vis-à-vis these two other controversial figures to whom Nixon knew - an early seventeenth-century reading public would relate him.

\section{Constructions of the Muslim world}

Although the idea of a Persian-Christian political and doctrinal alliance against the Ottomans appears central to several texts on or by the Sherleys, it was - perhaps surprisingly - not the major concern in Nixon's pamphlet. Certainly, Nixon reproduced the standard early modern descriptions of the Great Sophy as a Muslim ruler who favoured Christians: according to Manwaring, the Sophy

\footnotetext{
${ }^{12}$ Essex represented the epitome of "old honour" until his failed rebellion (the "last honour revolt," as James put it, 1978:416) disgraced him; this honour was identified with aristocratic values such as a strong emphasis on martial deeds, a direct connection with blood ("honour by nature") and "nobility" as a synonym for honour, and opposed the emergent Bartolan concept of honour ("honour by nurture" or merit) that would develop in the seventeenth century (James 1978:405-415).
} 
was "almost a Christian in heart" (Ross 1933:225), and Nixon, recalling Robert Sherley's life in Persia, explains that the Sophy "tends such attentive care [to Christianity] [...] that he [Robert] doubteth not [...] he [the Sophy] may in time bee brought to become a Christian" (Nixon 1607:K4v). "Abel Pinçon also testifies to the Sophy's kindness to Christians: "He [Shah Abbas] is very gracious to strangers, specially to Christians" (Ross 1933:158).

In this respect, Anthony Sherley also appears to emphasize how, unlike the Turks, Persians were inclined to favour Christians: "He [the Turk] is an absolute and Tyrannous enemie to the Christians: Your Majesties Religion hath a charitable opinion of them [Christians]" (A. Sherley 1613:117). Although we should remember that Anthony is reproducing here what he seems to have said to the Sophy himself, it is still noteworthy how this opinion will significantly change less than a decade later, in his Spanish political treatise of 1622 Pesso politico de todo el mundo. There, Sir Anthony expresses a quite contrary vision of Persian attitudes towards Christians:

El Persiano tiene naturalmente más aborrecimiento a los christianos que no el turco, y lo que digo es demonstrativo pues que el turco a admitido siempre y admite conventos de religiosos y algo de espacioso término en sus estados a los christianos pero el Persiano nunca lo a hecho hasta que esta ocasión de rompimiento con el turco traxo el negocio a necessaria [...] y forzada conveniencia. $(83 \mathrm{v}-84)$

As I have shown, a strategic coalition between Persians and Christians to confront the Turks certainly appears as a possibility in the writings of Pinçon and Manwaring, albeit not on account of the Sophy's alleged sympathy towards Christians but because of the hostility that they perceived between Persians and Ottomans. This hostility - these authors claimed - was based on religious (sectarian) differences. Manwaring is very specific when referring to these dissensions within Islam: "as the Turks do hold the kindred of

\footnotetext{
${ }^{13}$ According to Manwaring the Sophy once said: "I do esteem more of the sole of a Christian's shoe, than I do of the best Turk in Turkey" (Ross 1933:208). But contemporaries of the Sherleys knowingly dismissed this idea as absurd: the notion of the Sophy as a potential convert to Christianity was, according to Cartwright, "more fitte for a Stage, for the common people to wonder at, then for any mans private studies" (Cartwright 1611:70-71).
} 
Mahomet in great reverence amongst them, so the Persians do contrary unto them" (Ross 1933:217). Pinçon, for his part, remarks that "the Persians hold the Turks in great abomination, saying that they are impure in their law" (Ross 1933:163). Also, Nixon explains this hatred in an insightful way:

The Persian praieth to Mahomet, and Mortus Ally, the Turkes both to them and three others, that were Mahomets servants, against which three, the Persian still inveighs, and is an enemie. (Nixon 1607:H2-H2v)

Through his reference to "Mortus Ally" Nixon is here showing the sophisticated knowledge of Islam that the Sherleys had. Indeed, the pamphleteer was developing, for an early modern English readership, some of the complexities of this religion by alluding to its two main branches: the Shi'a denomination, which was predominant in Persia, and the Sunna branch, the official version of Islam in Turkey. These sectarian differences were already known in England since the 1560s (Masood 2011:5-6), although what Manwaring, Pinçon or Nixon seem to be expressing is how "sectarian divisions within Christianity and Islam were thought to be interconnected, and how Catholic-Protestant-Shi'a-Sunni interests diverged and converged in the early modern world" (Masood 2011:6); this dissension, they implied, could favour the Sherleys' military and political projects (Ross 1933:162-163).

Stemming from these religious differences, the various narratives on and by the Sherleys elaborate on the possibilities of making these two powerful kingdoms confront each other. To achieve this, the English readership had to be persuaded that, firstly, the Ottomans were "the most inhumane of all other barbarians" (T. Sherley 1936:1) and that, secondly, they were "a shaddowe of greatness whyche former tymes have given him" (5). All three brothers (but especially Sir Anthony) attempted to present a convincing case for Persian interest in joining Christendom in such an alliance. For Nixon:

There are two sorts of Turkes: the natural Turke and the Renegado [...] and they are and have beene ever the most inhumane of all other Barbarians. Their maner of living is for the most part uncivill, and vitious. For their vices, they are all Pagans, and Infidels, Sodomites, and Liars [...] their pride is so great, as it is not possible to be described. Next that, followeth their crueltie, in which their kings exceed [...] The Turkes are beyond all 
measure, a most insolent, superbous, and insulting people, ever prest to offer outrage to any Christian. (Nixon $1607: \mathrm{H}_{4}-\mathrm{I}_{1}$ )

Nixon also states that, due to their decadence it would be easy for a league of Christian princes to defeat and convert them (Iiv). Sir Anthony, in his own narrative, expresses similar criticism of the Turks as he states that their power is declining due to their great corruption and hedonism, as the many successful rebellions taking place within the Ottoman empire prove (1613:105-115) ${ }^{14}$ In fact, in a long letter to Sir Robert Cecil in which he tries to excuse his behaviour between 1597 and 1601 (plotting against pro-Turkish English foreign policy), Sir Anthony tries to justify his support of the Persians by alluding to the Turks' alleged weakness:

The Turk being a friend to the Queen for State reasons, it may be asked why I moved the Persian against him, without Her Majesty's licence. It was because the Turk only favours the Queen for the sake of our trade [...] this amity is not useful, for his government is very weak; he cannot move the King of Spain, nor the Venetians, who are suspicious of him, to arms; and he could not put 50 galleys to sea. (Calendar of State Papers. Domestic, 160103 1870:223-224)

Sir Anthony also adds some hyperbolic praise of the Persians, in a clearly ideological attempt to justify his belief in the coalition he was trying to build

the fashion of his [ie, the Sophy's] governmêt differing so much from that which we call barbarousnesse, that it may justly serve for as great an Idea for a Principality, as Platoes Common-wealth did for a Government [...] The King gives the notablest example of true unpartiall royall iustice, that I thinke any Prince in the world can produce. [...] This king wee call barbarous, though from his example wee may learne many great and good things. (A. Sherley 1613:29; 67; 70)

But here we find, once again, how Sir Anthony's narratives can, after only a few years, easily contradict themselves in a substantial way. References to Persian greatness almost disappear from the description of Persia appearing in his Spanish Pesso politico de todo el mundo. Addressed to Philip IV's main counsellor and royal favourite,

${ }_{14}$ Thomas Sherley's Discourse of the Turks (ca. 1607-1608) is almost exclusively concerned with criticism of the Turks. Interestingly, Nixon's description of the Turks in $\mathrm{H}_{4}$ is almost identical to Thomas' on the first page of his treatise. 
the Count-Duke of Olivares, Pesso presents Persia as a hybrid community composed of "naturales persas" and "Turcomanos, Curdos y Tártaros," the latter being a majority of "Bárbaros inconsiderables [...] soberbios y en fin gente sin manera de ley" (80); they are also weak and inferior to the Turks ("desigualísimo al Turco" 82), and, as we saw, in no way may they accept Christians: "El Persiano tiene naturalmente más aborrecimiento a los christianos que no el turco" $(83 \mathrm{~V})$. This, of course, contradicts other judgments made by the Sherleys and his companions, which presented the Persian Sophy as "almost a Christian in heart," as Manwaring expressed it (Ross 1933:225), and Persian religion as closer to Christianity than the Turks' (A. Sherley 1613:117).

Evidently, Sir Anthony had good reason to act in this way: if by the time he wrote his autobiography he was interested in explaining to an English readership why he had gone rogue and become a Persian "ambassador" (never acting as an English envoy, although pretending to be one), in the 1620 s in Spain he tried to present his Persian adventure from the perspective of the risks involved for him when dealing with such "Bárbaros inconsiderables" (A. Sherley 1622:80), as well as the services he had rendered to Habsburg struggles against the Ottomans. His brothers were equally involved in similar activities of an uncertain political nature which they endeavoured to present in a positive light: Thomas Middleton's 1609 pamphlet Sir Robert Sherley was an attempt to convince its readership that Robert, who in fact was a pensioner of the Sophy, was acting in order to improve the influence of England in Persia; to that effect, Middleton made Robert's Persian mission "more palatable to the intended English audience" by removing from his pamphlet references to Robert's Catholicism, and excising allusions to his loyalty to Persia (Shand 1983:260). As for Thomas, his own pamphlet shows how, for all the hatred expressed, he did not return to England directly as soon as he was freed in Constantinople, but stayed there and, on returning to England in 1606, unsuccessfully tried to establish commercial relations with those Ottomans he had so bitterly demonized in his Discours of the Turkes (Ross 1936:3-15). 


\section{Conclusions: The Sherleys, England, and the Global Early Modern}

The Sherley Brothers were, by the late sixteenth century, alienated from their home country. Whereas Thomas returned to England in 1606, and Robert spent all his life as a Persian subject, periodically travelling through Europe as a genuine ambassador of the Great Sophy, ${ }^{15}$ Sir Anthony would never again set foot in England after 1597. King James's representative in Venice gave the Venetian ambassador a brief and only partial explanation of this:

[Sir Anthony Sherley] had not returned to England after his voyage to Persia for no other reason than that as a relation and dependent of the Earl of Essex, he would have been exposed to persecution by the opposite faction after the Earl's death. (Calendar of State Papers. Venetian 1603-1607 1900:35)

Albeit after the accession of James Stuart it could be thought he had nothing to fear, as Sir Anthony himself complained, the ghost of Essex seemed to haunt his life. Indeed, this statement was made when Sir Anthony - for reasons unclear to this day - had already decided not to return to England and enter into the service of various foreign monarchs: twice expelled from Venice, he served the Habsburg Emperor in Prague (who sent him to Morocco in 1605), ${ }^{16}$ and Philip III of Spain from 1607. As I noted above, in his Spanish treatise Pesso politico de todo el mundo Anthony Sherley affirmed that he had played an important role in the political plotting preceding the Armada failed invasion of 1588 , carrying letters (the content of which he claimed to know) between Mary Stuart, the Duke of Parma and the Earl of Leicester:

La carta de la reina de Escocia hera brebe pero apretada en el punto de remitirse en todo a la del Conde de Lexest [Leicester] [...] La carta del Conde hera amplia, y copiosa, tratando de muchos disgustos, que tenia con la Reina de Ynglaterra [...] y que

\footnotetext{
${ }^{15}$ Before his death in Persia in 1628 Robert had visited England twice, and he was received as the Sophy's ambassador by King James in 1611 and 1624, and briefly by King Charles in 1625.

${ }^{16}$ There is not much information about Sir Anthony's adventures in Morocco, although Robert Chambers's True Historicall Discourse of Muley Hamets Rising (1609) gives a succinct account of "the aduentures of Sir Anthony Sherley, and diuers other English gentlemen" (1609:front page). The Folger Shakespeare Library Hamnet catalogue gives a certain R. Cottington as possible author of this book, leaf A2r is signed Ro. C.
} 
si el Duque [of Parma] quisiese hacerse rey de Ynglaterra, al qual reino tenia un cierto derecho suio propio [...] tendria sus fines la intenzion de el rey de España aunque por otro modo, pues que el reino de Ynglaterra seria de Prinzipe siempre amigo y pariente suio. (A. Sherley 1622:164-164v)

In 1607 King Philip conferred on him the title of "Count" (he is called "Conde Antonio Xerly" in some Spanish documents of the 1620s) and he received a commission as "General of the Mediterranean sea" to fight Turks and Moors (Ross 1933:68-69), ${ }^{17}$ but he eventually failed in this capacity, in which he continued his selfassigned life mission, namely to unite all Christian princes against the Turks (Chew 1937:282-297,289). Yet as early as 1610 he had already fallen into disrepute with the Spaniards and was living, if not in poverty, certainly with modesty, a condition from which he would not recover, dying obscurely in Madrid in 1637 (Shirley 1848:98-100; Chew 1933:296-297; Ross 1937:84-85). ${ }^{18}$

The contradictory allegiances and troubled lives of the three Sherley brothers (especially of Sir Anthony's), and more specifically the various accounts of their lives and adventures, invite, as we have seen, an approach that conjoins early modern ideology, politics, and textuality. The conflicting versions of Sir Anthony and Robert's Persian embassy, their connections (never clarified) with Essex, King James or the Sophy, or the uncertain and often contradictory views of Persia and Turkey offered in these texts, are inextricably bound up with the (literally) textual construction of the adventures of the three brothers. From Nixon's encomiastic pamphlet to Don Juan's merciless description of Anthony's lack of ethics, from Anthony's and Thomas' self-aggrandizing autobiographies, and Parry's and Manwaring's sympathetic accounts of the former, to Pinçon's more detached (but nevertheless partial) depiction of the same events, all these texts conflict and permeate each other in a constant interplay of fact and fiction which eventually seems to suggest that a noncontradictory Sherleyan narrative is irretrievable. In the blurred and ambiguous writings of these three Elizabethan adventurers, English nationhood interacts with an early modern unchauvinistic culture of

\footnotetext{
17 And also the Dutch, but interestingly not the English or the Venetians (Chew 1933:283-289).

${ }^{18}$ The Reverend James Granger, in his Biographical History of England, writes that Anthony Sherley died in Spain in the 1630 .
} 
foreign relations (Parr 1995:20), and these suggest a specific political form through which various apparently opposed identities (Catholic or Persian, honourable or infamous) are constructed. In the words of Alison Games, like true "cosmopolitans" the Sherley brothers (and very notably Sir Robert and Sir Anthony), to a degree

demonstrated their interest in and sympathy for foreign mores, worked with and for foreigners, sometimes immersed themselves in foreign worlds, and gradually dislodged themselves from unthinking attachments to a single nation. (2007:25).

But the early modern travel trope, which in drama depicted a movement from departure (including exile), to the experience abroad, and concluded with the return home, is here disrupted by the impossibility of returning: Robert died in Persia, probably after having realized that he was no longer an Englishman; and Anthony remained an exile all his life. ${ }^{19}$ However, Anthony's departure and life-long estrangement from England were as much the consequence of circumstances (as he repeatedly tried to convince Cecil) as his own will, as many of his activities, notably his relatively unknown service for the Spanish crown in 1588, or his Persian adventure, seem to prove.

Narratives by and about the Sherleys are cultural, semiotic and material artefacts, produced in an ideological periphery (England's others, either Catholic or Muslim), and involve a diversity of boundaries (or "frontiers") crossed and of foreign customs confronted with national ones. This engages with Yuri Lotman's notion of the "Other:"

Since the boundary is a necessary part of the semiosphere and there can be no "us" if there is no "them," culture creates not only its own type of internal organization but also its own type of external "disorganization." In this sense we can say that the "barbarian" is created by civilization and needs it as much as it needs him. (2001:142)

It is hard to say who exactly were Anthony Sherley's "barbarians," as Persians, Turks, Spaniards or Englishmen were at turns, and somewhat contradictorily reproduced (or "created") as friends and

\footnotetext{
${ }^{19}$ Thomas, who peacefully died in the Isle of Wight in 1625 (the only brother to return to England), did not recover the family estate at Wiston, and spent some months in prison (Ross 1933:286-287).
} 
foes, civilized and wild. The "real" narrative of the Sherleys, therefore, does not exist, and it is as contradictory and irretrievable as the "Sherley myth." Texts have memory, and this might be defined as "the sum of the contexts in which a given text acquires interpretation" (Lotman 2001:19). In this essay I have tried to recover part of the memory of the previous contexts of these various texts, since the "culture of preceding ages inevitably comes down to us in fragments" (19), although I realize that the "memorable actes [...] [and] noble deedes" (Nixon 1607:B) of the three brothers will remain, to a large extent, a mosaic (a palimpsest) of disconnected fragments. And what this density of narratives tells us is precisely that, in more than one way, the Sherleys eventually become in these texts as alienated as the "others" they were trying to know and, ultimately, exploit for their own ends. Like these "others" (and like their own patron the Earl of Essex) their textual construction inevitably illustrates the extent to which they had become as difficult to reduce to a single narrative as the "spirits" Nixon refers to in his pamphlet (1607:B). Although not due to the fact that they had been "unkindly used by us [...] of the English Nation," Nixon was unknowingly right when he concluded that the three Sherley brothers had eventually become "strangers here at home" (1607:B2).

\section{References $^{20}$}

Andrea, Bernadette 2008. Women and Islam in Early Modern English Literature. Cambridge: Cambridge University Press.

Anon. 1933 (1600). "A True Report of Sir Anthony Sherley's Journey." Ed.

E.D. Ross. Sir Anthony Sherley and his Persian Adventure. London: The Broadway Travellers: $91-97$.

Bak, Greg 1996. "Different Differences: Locating Moorishness in Early Modern English Culture." Dalhousie Review 76/2: 197-216.

Brown, H.F. ed. 1900. Calendar of State Papers. Venetian 1603-07. London.

Burton, Jonathan 2005. Traffic and Turning. Islam and English Drama, 15791624. Newark: University of Delaware Press.

${ }^{20}$ Short Title Catalogue (STC) references are to the second edition (Pollard and Redgrave 1976-1991). All primary sources in English have been consulted at the Folger Shakespeare Library (Washington DC, US), and those in Spanish at the Biblioteca Nacional de España in Madrid. 
2009. "The Shah's Two Ambassadors: The Travels of the Three English Brothers and the Global Early Modern." Eds. B. Charry and G. Shahani. Emissaries in Early Modern Literature and Culture. Abingdon: Ashgate: 2340.

Cartwright, John 1611. The Preachers Travels. London. [STC 4705].

Ch[ambers], R[obert] 1609. A true historicall discourse of Muley Hamets rising to the three kingdoms of Moruecos, Fes, and Sus. London. [STC 430o].

Chew, Samuel C. 1937. The Crescent and the Rose. Islam and England during the Renaissance. New York: Oxford University Press.

Day, John, William Rowley, and George Wilkins 1607. The Travailes of the Three English Brothers. [STC 6417].

Dimmock, Mathew 2005. New Turkes. Dramatizing Islam and the Ottomans in Early Modem England. Aldershot: Ashgate.

Games, Alison 2007. "England Global Transition and the Cosmopolitans who made it Possible." Shakespeare Studies 35: 24-31.

Ghatta, Javad 2009. "'By Mortus Ally and our Persian Gods': Multiple Persian Identities in Tamburlaine and The Travels of the Three English Brothers." Early Theatre: A Journal Associated with the Records of Early English Drama [special issue of Early Modern English Drama and the Islamic World] 12/2: 235-249.

Gil, Luis 1985. "Sobre el trasfondo de la embajada del Shah Abbas I a los príncipes cristianos: Contrapunto de las Relaciones de Don Juan de Persia." Eclás 27/89: 347-377.

Granger, James 1769. Biographical History of England. London.

Green, M.A.E. 1870. Calendar of State Papers. Domestic Series. 1601-1603. London.

- 1871. Calendar of State Papers. Domestic Series. Addenda. 1566-1579. London.

Greenblatt, Stephen 1997. The Norton Shakespeare. New York: Norton.

Hakluyt, Richard 1903. The Principall Navigations, Voyages, Traffiques and Discoveries of the English Nation. 12 vols. Glasgow: J. MacLehose and sons.

Houston, Chloë 2009. "'Thou glorious kingdome, thou chiefe of Empires': Persia in Early Seventeenth-century Travel Literature." Studies in Travel Writing 13/2: 141-152.

James, Mervyn 1978. Society, Politics and Culture. Cambridge: Cambridge University Press.

Jones, Norman 1978. "The Adaptation of Tradition: The Image of the Turk in Protestant England." East European Quarterly 12/2: 161-175. 
(c) ederi 23 (2013)

Knolles, Richard 1610 (1603). The generall historie of the Turkes. London: Adam Islip. [STC 15052].

Lotman, Jüri M. 2001. Universe of the Mind. A Semiotic Theory of Culture. London \& New York: Tauris.

McJannet, Linda 2009. "The Translator as Emissary: Continental Works about the Ottomans in England." Eds. B. Charry and G. Shahani. Emissaries in Early Modern Literature and Culture. Abingdon: Ashgate: 147166.

Manwaring, George 1933 (ca. 1601). "A True Discourse of Sir Anthony Sherley's Travel into Persia." Ed. E.D. Ross. Sir Anthony Sherley and his Persian Adventure. London: The Broadway Travellers: 175-226.

Masood, Hafiz A. 2012. "From Cyrus to Abbas: Staging Persia in Early Modern England." Doctoral thesis. University of Sussex.

Matar, Nabil 1998. Islam in Britain. Cambridge: Cambridge University Press.

Menocal, María Rosa 2002. The Ornament of the World. How Muslims, Jews, and Christians Created a Culture of Tolerance in Medieval Spain. New York \& Boston: Little Brown.

Middleton, Thomas 1609. Sir Robert Shirley. London. [STC 17894]

Newton, Thomas 1575. A notable history of the saracens. London. [STC 6129]

Nixon, Anthony 1607. The Three English Brothers. London. [STC 18592].

Parr, Anthony 1995. "Introduction." Ed. A. Parr. Three Renaissance Travel Plays. Manchester \& New York: Manchester University Press: 1-54.

- 1996. "Foreign Relations in Jacobean England: The Sherley Brothers and the Voyage of Persia." Eds. J.P. Maquerlot and M. Willems. Travel $\mathcal{E}$ Drama in Shakespeare's Time. Cambridge: Cambridge University Press: 1431.

Parry, William 1933 (1601). "A New and Large Discourse of the Travels of Sir Anthony Sherley, Knight." Ed. E.D. Ross. Sir Anthony Sherley and his Persian Adventure. London: The Broadway Travellers: 98-136.

Persia, Don Juan de 1946 (1604). Relaçiones de don Juan de Persia. Ed. N. Alonso. Madrid: Ultra.

Persia, Don Juan de (Uruch Beg) 1929 (1604). Don Juan de Persia. A Shi'ah Catholic. Ed. E.D. Ross and E. Power. Trans. G. Le Strange. London: Harper (The Broadway Travellers).

Pinçon, Abel 1651 (1605). Relation d'un voyage de Perse. Paris.

Pollard, Alfred W. and Gilbert R. Redgrave eds. 1976-1991 A short-title catalogue of books printed in England, Scotland, $\mathcal{E}$ Ireland and of English books printed abroad, 1475-1640. London: Bibliographical Society. $2^{\text {nd }}$ edition. 
Publicover, Laurence 2010. "Strangers at home: the Sherley brothers and dramatic romance." Renaissance Studies 24/5: 694-709.

Purchas, Samuel 1905 (1625). Purchas His Pilgrimes. Vol. 1. Glasgow: J. Maclehose.

Ross, E. Dennison 1933. Anthony Sherley. His Persian Adventure. London: Routledge.

Sainsbury, W. N. Esq. ed. 1964. Calendar of State Papers. Colonial Series. 15131616. Public Record Office. Vaduz: Kraus.

Sha'ban, Fuad 1965. "The Mohammedan World in English Literature, ca. 1580-1642. Illustrated by a Text of The Travailes of the Three English Brothers." Doctoral thesis, Duke University.

Schleck, Julia 2011. Telling True Tales of Islamic Lands. Selinsgrove, PA: Susquehanna University Press.

Shand, G.B. 1983. "Source and Intent in Middleton's Sir Robert Sherley." Renaissance and Reformation 19: 257-264.

Sherley, Anthony 1613. Sir Anthony Sherley his relation of his travels into Persia. London. [STC 22424]

— [Xerly, Conde Antonio] 1622. Pesso político de todo el mundo. Madrid.

Sherley, Thomas 1936 (ca. 1607-08). Discours of the Turkes. Ed. E. Denison Ross. Camden Third Series. London: Offices of the Royal Historical Society.

Shirley, Evelyn P. 1848. The Sherley Brothers. Chiswick.

Singh, Jyotsna G. 2009. A Companion to the Global Renaissance. English Literature and Culture in the Era of Expansion. Malden, MA and Oxford: Wiley-Blackwell.

How to cite this article:

López-Peláez Casellas, Jesús. "Strangers at home: The Textual Construction of the Sherley Brothers." SEDERI 23 (2013): 33-56.

Author's contact: jlopez@ujaen.es

Submission: 13/02/2013 - Acceptance: 10/04/2013 